
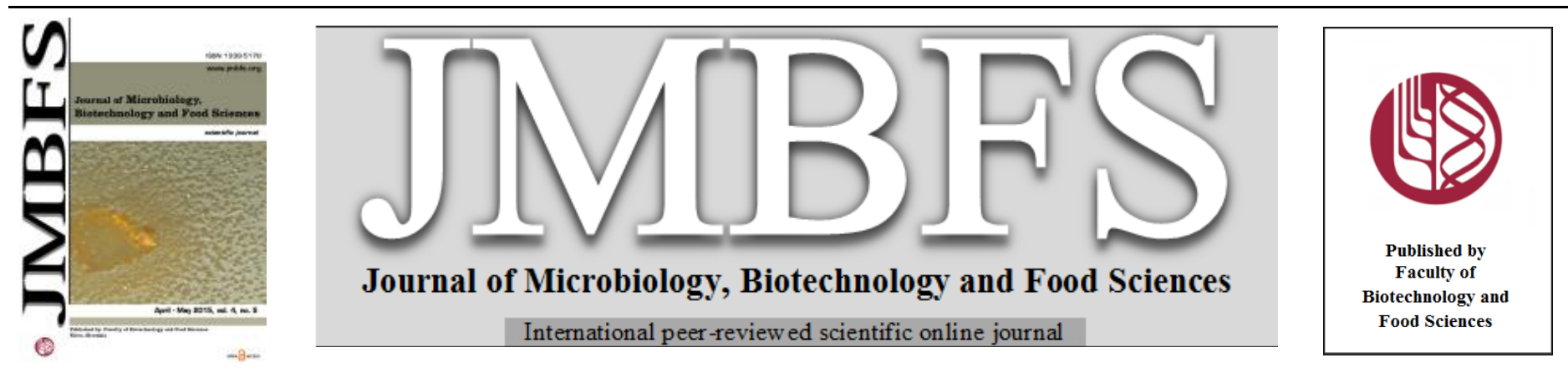

\title{
UTILIZATION OF MUSTARD OIL FOR THE PRODUCTION OF POLYHYDROXYALKANOATES BY Pseudomonas aeruginosa
}

\author{
Hasnain Javed $*^{l}$, Nazia Jamil
}

Address(es): Mr. Hasnain Javed (Corresponding author)

${ }^{1}$ Universty of the Punjab, faculty of Life sciences, Department of Microbiology and Molecular Genetics, Quaid-e-Azam Campus Lahore-54590, Pakistan.

*Corresponding author: hasnain_javed@hotmail.com

doi: $10.15414 / j m b f s .2015 .4 .5 .412-414$

\section{ARTICLE INFO}

Received 10. 12. 2014

Revised 15. 1.2015

Accepted 16.2.2015

Published 1. 4. 2015

Regular article open $\partial$ access

\begin{abstract}
With the unnecessary use of plastics and cumulative pressure being placed on capacities available for plastic waste disposal, the need for biodegradable plastics and biodegradation of plastic wastes has assumed increasing importance in the last few years. Bioplastic production from mustard oil was considered relatively cheap, easily available, included in vegetable oil and don't having much volatile characteristics. Total of 67 bacterial strains were isolated and purified from different regions of the Pakistan, and were checked for Polyhydroxyalkanoates (PHA) production by Sudan black and Nile blue staining. Quantitative analysis for biodegradable plastic produced by different bacterial species was performed by Modified surfactant hypochlorite method. High PHA production was detected in 35 strains belonging to different genera including Pseudomonas, Staphylococcus, Escherichia and Enterobacter. Fermentation and PHA production was done in batch culture. The PHA production of $P$. aeruginosa by mustered oil cultivation was studied under six experimental conditions, such as air flow rates, $\mathrm{pH}$, Temperature, optical density, substrates concentration and cell dry weight. PHA production of Pseudomonas species were subsequently authenticated at molecular level by PCR amplifications and sequence analysis. PHA polymerase $1(\mathrm{PhaCl})$ and PHA polymerase $2(\mathrm{PhaC2})$ from Pseudomonas aeruginosa were amplified, sequenced and submitted to gene bank.
\end{abstract}

Keywords: Polyhydroxyalkanoates, Pseudomonas aeruginosa, Mustard oil, batch culture fermentation

\section{INTRODUCTION}

PHAs are recognized as biodegradable plastics as they possess material properties similar to synthetic thermoplastics and are easily degraded to water and carbon dioxide (and methane under anaerobic conditions) by enzymatic action of microbes in various environments such as soil, sea water, lake water, and sewage (Kung et al., 2007; Chaudhry et al., 2011). Synthetic plastics, although are non-degradable and pose one of the major causes of environmental pollution (Bhuwal et al., 2013), are used because the use of plastics cannot be eradicated from our daily life at all. To solve the current problem of environmental pollution, interests have been shifted to the development of bioplastics because they provide dual benefits of utilizing the waste and costeffective production of biodegradable plastic (Ramezani et al., 2014).

For the commercialization of PHA, inexpensive carbon sources are required. Therefore, research efforts are abound to exploit inexpensive raw materials as substrates in order to reduce the high cost of PHAs production (Iles and Martin, 2013). Different efforts are in process to reduce the PHA production cost (Wang et al., 2014). A good candidate for PHAs production would be a bacteria that can store high level of PHAs using inexpensive substrate. Numerous inexpensive carbon substrates such as molasses, whey, plant oils etc. can be excellent substrates for bacteria to produce PHAs, which could lead to substantial economic benefits (Ciesielski et al., 2014). In an attempt to reduce production costs in the recent years, focus has shifted to the use of less valuable, renewable materials as substrates for PHA production, as soy molasses (Solaiman et al. 2006), wheat-based co-products (Koutinas et al., 2007), refined and crude glycerol (Cavalheiro et al., 2009; Zhu et al., 2010; Ashby et al., 2011).

The isolation and the purification of bacterial PHAs are the key step of the process profitability in the fermentation system (Khan et al., 2013). Detailed studies have been carried out to investigate that which fermentation system i.e. batch, fed-batch or continuous fermentations is efficient for the desired PHA. The ideal method should lead to a high purity and recovery level at a low production cost. To achieve the volumetric productivity and to develop a comparatively economically competitive method for the production of PHAs, various factors are very important like choice of bacterial strain, optimized conditions and most importantly the choice of media and carbon sources which have direct influence on production cost (Lau et al., 2014). So to reduce the bioplastic production cost as compared to the production cost of synthetic plastics, there is an urgent need to find the cheaper media with necessary requirements and cheaper carbon source for the PHA (Allen et al., 2010). More than 59 PHA synthase genes have been cloned from 45 bacterial species and broadly characterized into four different classes, based on their in vivo substrate specificities, amino acid sequences, and subunit composition (Tajima et al., 2012). Class I and class II PHA synthases comprise enzymes consisting of only one type of subunit phaC (Yang et al., 2013). Pseudomonas is highly stress resistant bacteria and often isolated from different minimal nutrient environments (Caton et al., 2014). The class II PHA synthase genes phaC1 and phaC2 that favor mcl 3PHA have been identified and characterized in Pseudomonas sp. including Pseudomonas aeruginosa), Pseudomonas oleovorans (Tan et al,. 2010). The different studies showed that both of them exhibit very similar properties (Rehman et al., 2007).

Objective of our study was to find out cost effective substrate for PHA production. For this purpose, soil and waste water isolates were characterized, their PHA production ability with different carbon sources was optimized and molecular characterization of phaC, phaC1 and phaC2 genes were done. After that Mustard oil was used as carbon source in lab scale fermenter and PHA production was compared with Glucose.

\section{MATERIAL AND METHODS}

\section{Sampling and growth of PHA producing bacteria}

Soil and waste water samples were collected from different areas of Pakistan and were plated on PHA detection media (PDA) containing $2 \mathrm{~g} / 1\left(\mathrm{NH}_{4}\right)_{2} \mathrm{SO}_{4}, 13.3 \mathrm{~g} / \mathrm{l}$ $\mathrm{KH}_{2} \mathrm{PO}_{4}, 1.2 \mathrm{~g} / 1 \mathrm{MgSO}_{4} .7 \mathrm{H}_{2} \mathrm{O}, 1.7 \mathrm{~g} / \mathrm{l}$ citric acid, trace element solution $10 \mathrm{ml} / \mathrm{l}$, $5 \mu \mathrm{g} / \mathrm{ml}$ Nile blue, $2 \%$ carbon source (glucose or mustard oil), incubation was given at $37^{\circ} \mathrm{C}$ for 24 to 48 hours.

\section{Microscopy for PHA detection}

PHA granules or PHA inclusion bodies were detected in the cells using Sudan Black staining method in which heat fixed bacterial smear (from bacterial strain 
grown in PHA accumulating conditions) was treated with $0.3 \%$ Sudan Black B (in ethylene glycol) for 5-15 minutes. Then washed with several times dipping in xylene and counter stained with safranine and rinsed.

\section{Time profiling and PHA extraction}

Time profiling of PHA production was also done by taking the sample out in regular intervals of 2 hours (0-72 hours) and total biomass weight was measured by taking optical density of sample at $600 \mathrm{~nm}$. PHA producer Bacterial cells grown in PDA medium (liquid culture) for 72 hours were collected by centrifugation and biomass was re-suspended in $1: 1$ ratio of $0.4 \%$ sodium hypochlorite for one hour and then dissolved in chloroform. PHA granules were collected by centrifugation and the pellet was washed with alcohol and chloroform. The percentage of PHA in bacterial strain was noted with the formula:

PHA\% = weight of $\mathrm{PHA} /$ weight of biomass $\times 100$

\section{Isolation and molecular characterization of DNA}

For molecular characterization genomic and plasmid DNA was extracted using phenol chloroform method and was subjected to 16s rRNA sequencing. DNA was subjected to amplification with forward primer 16S-3, CCCGGGAACGTATTCACCG and reverse primer 16S-5, GCYTAAYACATGCAAGTCGA (Chaudhry et al., 2011) under the conditions like denaturation at $95^{\circ} \mathrm{C}$, annealing at $52^{\circ} \mathrm{C}$ and extension at $72^{\circ} \mathrm{C}$. Gene sequencing was done with chain termination method and sequence alignment was checked using NCBI BLAST.

\section{Identification and amplification of phaC gene from PHA producers}

The 16S rRNA gene was sequenced at the Center for Excellence in Molecular Biology, (Pakistan) by Sanger sequencing method. The phaC polymerase gene was amplified using forward primer $179-\mathrm{L}$ and the reverse primer $179-\mathrm{R}$ (Chaudhry et al., 2011). PCR was carried out by denaturing DNA at $110^{\circ} \mathrm{C}$ for 10 min followed by 30 cycles of amplification $\left(95^{\circ} \mathrm{C}\right.$ for $2 \mathrm{~min}, 56^{\circ} \mathrm{C}$ for $1 \mathrm{~min}$ and $72^{\circ} \mathrm{C}$ for $2 \mathrm{~min}$ ). The phaC1 and phaC2 gene extensions of phaC were also amplified using the ORF primers for Pseudomonas denaturation at $95^{\circ} \mathrm{C}$, annealing temperature $58^{\circ} \mathrm{C}$ and extension at $72^{\circ} \mathrm{C}$ for 2 minutes each.

\section{PHA production using different carbon sources}

Using the batch culture conditions PHA producing strain was grown in 5 liter lab scale fermenter of Bioengineering Company using glucose and mustard oil as the carbon source in two different reactions. Comparisons of PHA production and growth and survival conditions were noted by taking samples out of the fermenter with the regular intervals of 2 hours for 3 consecutive days.

\section{RESULTS AND DISCUSSION}

\section{Isolation and characterization of PHA producing bacterial strains:}

A total of 67 bacterial strains were isolated from 15 different samples collected from various areas of Pakistan. Out of these 27 samples showed positive results for PHA production in PDA media contacting Nile blue (Figure 1A) and confirmed production by microscopic analysis with Sudan Black staining (Figure 1B).
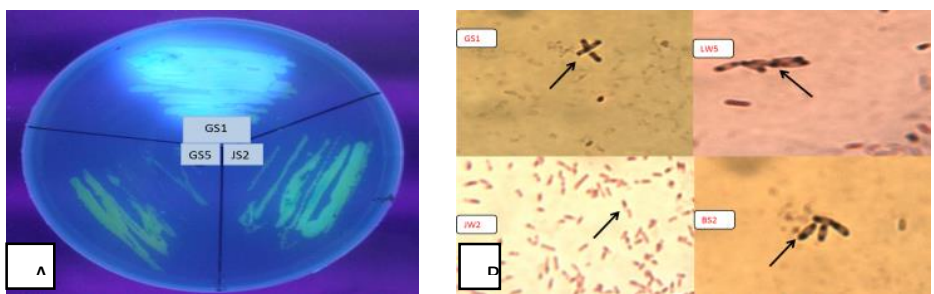

Figure 1 Characterization of PHA producing bacterial strains. 1A: Nile blue staining. 1B: Strains positive for PHA production showing granules on sudan black staining.

Biochemical characterization of all PHA producing stains was done and genus identification was done as Staphylococci (07), Enterobacter (04), Klebsiella (02), Pseudomonas (11), and Bacillus (05) (Table 1). Pseudomonas strains showed high percent PHA production and better growth compared to all other strains and their 16s rRNA ribotyping was done. Different bacterial strains have been noted to form these biopolymers but there is need to minimize the production and bacterial cultivation cost to get more advantage from these polymeric substances. Strain GS1 showed homology to $P$. auregenosa on the basis of ribotyping. The $16 \mathrm{~S}$ rRNA gene partial sequence was submitted to the NCBI database under the accession number HM598296.

Table 1 Genus identification of strains found positive for biopolymers production

\begin{tabular}{|c|c|c|c|c|c|c|c|}
\hline $\begin{array}{l}\text { Sample } \\
\text { type }\end{array}$ & Area & $\begin{array}{c}\text { Strain } \\
\text { code }\end{array}$ & Genus & $\begin{array}{l}\text { Sample } \\
\text { type }\end{array}$ & Area & $\begin{array}{c}\text { Strain } \\
\text { code }\end{array}$ & Genus \\
\hline \multirow{14}{*}{ Water } & \multirow{3}{*}{ Lahore } & LW2 & Staphylococcus & \multirow{14}{*}{ Soil } & \multirow{3}{*}{ Lahore } & $\mathrm{LS} 2$ & Staphylococcus \\
\hline & & LW4 & Escherichia & & & LS3 & Bacillus \\
\hline & & LW5 & Pseudomonas & & & LS6 & Bacillus \\
\hline & \multirow{3}{*}{ Gujrat } & GW1 & Staphylococcus & & \multirow{3}{*}{ Gujrat } & GS1 & Pseudomonas \\
\hline & & GW3 & Pseudomonas & & & GS4 & Klebsiella \\
\hline & & GW5 & Staphylococcus & & & GS6 & Pseudomonas \\
\hline & \multirow{2}{*}{ Kasoor } & KW2 & Klebsiella & & \multirow{2}{*}{ Kasoor } & KS1 & Enterobacter \\
\hline & & KW5 & Pseudomonas & & & KS3 & Pseudomonas \\
\hline & \multirow{2}{*}{ Jehlum } & JW2 & Pseudomonas & & Jehlum & JS1 & Pseudomonas \\
\hline & & JW3 & Bacillus & & \multirow{2}{*}{ Bhakkar } & BS2 & Pseudomonas \\
\hline & \multirow{2}{*}{ Bhakkar } & BW1 & Escherichia & & & BS4 & Staphylococcus \\
\hline & & BW2 & Pseudomonas & & & $\mathrm{SS} 1$ & Bacillus \\
\hline & Sheikhupura & SW1 & Pseudomonas & & Sheikhupura & $\mathrm{SS} 2$ & Staphylococcus \\
\hline & - & - & - & & & SS4 & Bacillus \\
\hline
\end{tabular}

Optimization of PHA production in different carbon sources

Our aim was to get the production of PHA using cost-effective sources of carbon. Using glucose and mustard oil as carbon sources, the PHA production was checked and growth conditions were optimized in separate reactions. Figure 2 shows the results for the PHA production and its percent in the cell dry weight at different time intervals. This is in agreement with (Ng KS et al., 2010) and (Rehman et al., 2007) as linear polyesters- polyhydroxyalkanoates are produced naturally by bacteria as the reserve materials for carbon and energy; along with this these are used as the source of bio-plastics. High carbon to nitrogen ratio, lack of certain macro and trace elements during growth, and excess of carbon cause certain microorganisms to store energy in this form. As these biopolymers are biodegradable so they are getting important in agriculture, economy and health sciences. Plant oils are desirable feedstock for PHAs production because they are relatively cheap as compared to most sugars (Le Meur et al., 2012). In search of inexpensive carbon source, mustard oil was chosen in this study as it is cheap, easily available and less volatile.

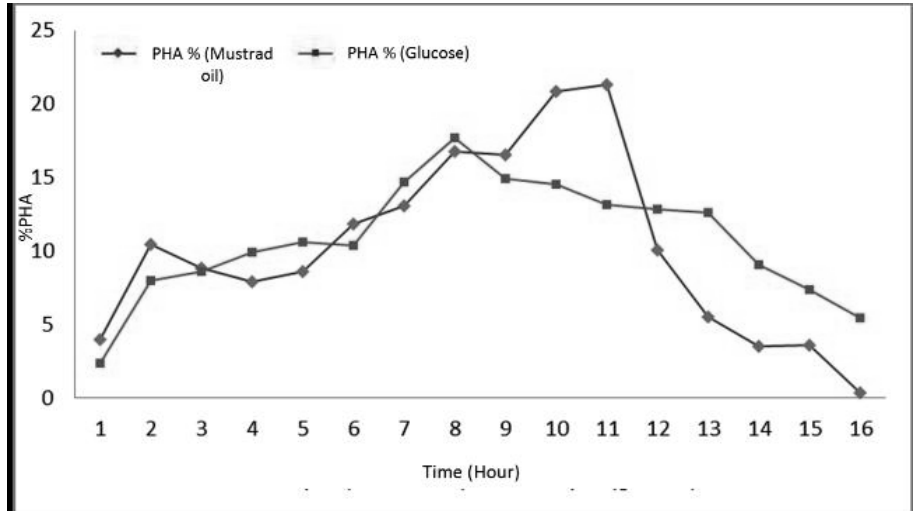

Figure 2 Comparison of PHA percentage (PHA \%) of two carbon source (Glucose and Mustard oil) from GS1 strain 


\section{Characterization of phaC gene from strain GS1}

From PHA producing strain GS1 which was Pseudomonas aeruginosa, phaC gene was amplified and $540 \mathrm{bp}$ product was successfully sequenced and submitted to NCBI gene bank under the accession number HM598297. Results indicated the homology with the Pseudomonas aeruginosa gene for PHA production. Along with this using ORF primers for Pseudomonas region adjacent to phaC was amplified named phaC1 and phaC2 (Figure. 3) and submitted to NCBI gene bank under the accession number HM598298. Sequencing results indicated the homology of this region with the phaC flanking regions of the operon.

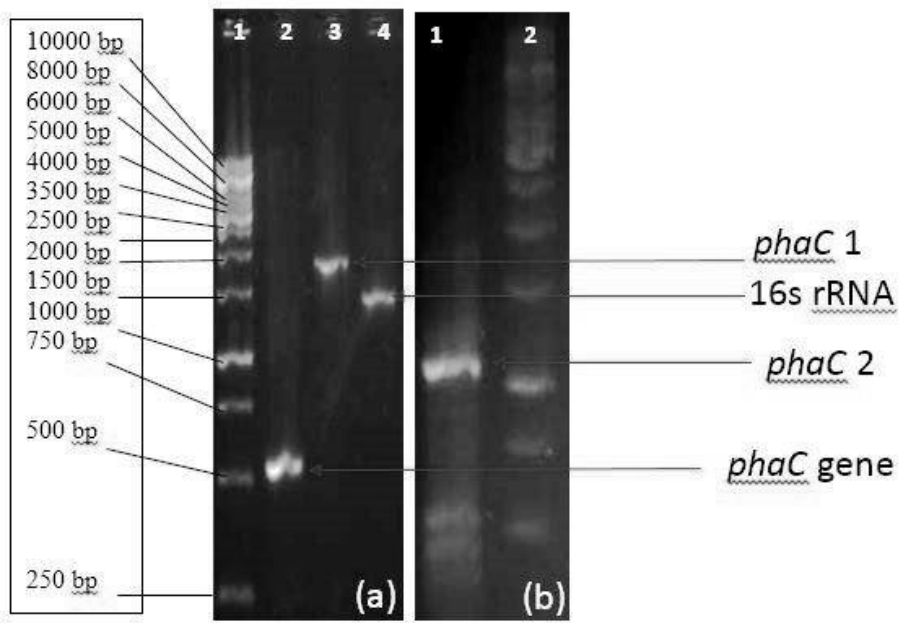

Figure 3 PCR amplification of genes. (a) Lane 1 is indicating gene ruler $(1 \mathrm{~kb})$ while lane 2,3 and 4 showing phaC (540bp), phaC1 (1700bp) and 16s rRNA (1500bp) gene respectively (b) Lane 1 is showing phaC 2 gene and lane 2 is showing gene ruler.

\section{CONCLUSION}

Our strain GS1 gave the maximum yield of PHA in lab scale fermenter when all the conditions like as air flow rates, $\mathrm{pH}$, Temperature, Optical density, substrates concentration and dry cell weight were under controlled. PHA production was at its peak at $30^{\text {th }}$ hour of fermentation process and it produced 9.01 gram/liter of PHA (20.1 \%PHA). So it is concluded that Mustard oil is also cheap carbon source for bioplastic production as it is easily available in South Asia and its use can lead to bio-plastic production at commercial level.

Acknowledgement: It is acknowledged that this research work was supported by International Foundation for Science (IFS) Sweden and University of the Punjab Lahore, Pakistan.

\section{REFERENCES}

ALLEN, A. D., ANDERSON, W. A., AYORINDE, F. O., \& ERIBO, B. E. 2010 Biosynthesis and characterization of copolymer poly (3HB-co-3HV) from saponified Jatropha curcas oil by Pseudomonas oleovorans. Journal of industrial $\begin{array}{llll}\text { microbiology } \quad \& \quad \text { biotechnology, 37(8), } & 849-856\end{array}$ http://dx.doi.org/10.1007/s10295-010-0732-7

ASHBY, R.D., SOLAIMAN, D.K., AND STRAHAN, G.D. 2011. Efficient utilization of crude glycerol as fermentation substrate in the synthesis of poly (3hydroxybutyrate) biopolymers. Journal of American oil chemist's society, 88(7) 949-959. http://dx.doi.org/10.1007/s11746-011-1755-6

BHUWAL, A.K., SINGH, G., AGGARWAL, N.K., GOYAL, V., YADAV, A. 2013. Isolation and Screening of Polyhydroxyalkanoates Producing Bacteria from Pulp, Paper, and Cardboard Industry Wastes. International journal of biomaterials. http://dx.doi.org/10.1155/2013/752821

CATONE, M. V., RUIZ, J. A., CASTELLANOS, M., SEGURA, D., ESPIN, G. \& LÓPEZ, N. I. 2014. High Polyhydroxybutyrate Production in Pseudomonas extremaustralis Is Associated with Differential Expression of Horizontally Acquired and Core Genome Polyhydroxyalkanoate Synthase Genes. PloS one,9(6), e98873. http://dx.doi.org/10.1371/journal.pone.0098873

CAVALHEIRO, J.M., DE ALMEIDA, M., GRANDFILS, C., DA FONSECA M. 2009. Poly (3-hydroxybutyrate) production by Cupriavidus necator using waste glycerol. Process Biochemistry. 44(5), 509-515. http://dx.doi.org/10.1016/j.procbio.2009.01.008

CIESIELSKI, S., MOŻEJKO, J., PISUTPAISAL, N. 2014. Plant oils as promising substrates for polyhydroxyalkanoates production. Journal of Cleaner Production. http://dx.doi.org/10.1016/j.jclepro.2014.09.040
CHAUDHRY, W.N., JAMIL, N., ALI, I., AYAZ, M.H., HASNAIN, S. 2011 Screening for polyhydroxyalkanoate (PHA)-producing bacterial strains and comparison of PHA production from various inexpensive carbon sources. Annals of microbiology, 61(3), 623-629. http://dx.doi.org/10.1007/s13213-010-0181-6 ILES, A., MARTIN, A.N.2013. Expanding bioplastics production: sustainable business innovation in the chemical industry. Journal of cleaner production, 45 38-49. http://dx.doi.org/10.1007/s13213-010-0181-6

LE, M., SYLVAINE, M.Z., THOMAS, E., LINDA, T-M, QUN, R. 2012 Production of medium-chain-length polyhydroxyalkanoates by sequential feeding of xylose and octanoic acid in engineered Pseudomonas putida KT2440. BMC biotechnology, 12(1), 53. http://dx.doi.org/10.1186/1472-6750-12-53

KHAN, A.B., MEHMOOD, I.K., OMER, M.T., FARZANA, H., KHALID, J. ARFA, Y., SHOUKAT, P. 2013. Separation of polyhydroxyalkanoatesproducing bacterial strains using PHA synthase gene and their evaluation for PHA deposition. Brazilian Archives of Biology and Technology, 56(4), 645-652. http://dx.doi.org/10.1590/s1516-89132013000400015

KOUTINAS, A.A., XU Y, W. R., WEBB, C. 2007. Polyhydroxybutyrate production from a novel feedstock derived from a wheat-based biorefinery. $\begin{array}{llll}\text { Enzyme } & \text { microbial technology, 40(5), } & 1035\end{array}$ 1044. http://dx.doi.org/10.1016/j.enzmictec.2006.08.002

KUNG, S.S., CHUANG, Y.C., CHEN, C.H., CHIEN, C.C. 2007. Isolation of polyhydroxyalkanoates-producing bacteria using a combination of phenotypic and genotypic approach. Letters of Applied Microbiology, 44(4), 364 371. http://dx.doi.org/10.1111/j.1472-765x.2006.02090.x

LAU, N. S., CH'NG, D. H. E., CHIA, K. H., WONG, Y. M., \& SUDESH, K. 2014. Advances in Polyhydroxyalkanoate (PHA): Unraveling the Development and New Perspectives. Journal of Biobased Materials and Bioenergy, 8(2), 118 129. http://dx.doi.org/10.1166/jbmb.2014.1418

NG, K.S., OOI, W.Y., GOH, L.K., SHENBAGARATHAI, R., SUDESH, K 2010. Evaluation of jatropha oil to produce poly (3-hydroxybutyrate) by Cupriavidus necator H16. Polymer Degradation and Stability, 95(8), 1365-1369 http://dx.doi.org/10.1016/j.polymdegradstab.2010.01.021

REHMAN, S., JAMIL, N., HUSNAIN, S. 2007. Screening of different contaminated environments for polyhydroxyalkanoates-producing bacteria strains. Biologia, 62(6), 650-656. http://dx.doi.org/10.2478/s11756-007-0144-y RAMEZANI, M., AMOOZEGAR, M.A., VENTOSA, A. 2014. Screening and comparative assay of poly-hydroxyalkanoates produced by bacteria isolated from the Gavkhooni Wetland in Iran and evaluation of poly- $\beta$-hydroxybutyrate production by halotolerant bacterium Oceanimonas sp. GK1. Annals of Microbiology, 1-10. http://dx.doi.org/10.1007/s13213-014-0887-y

SAMBROOK, J., RUSSELL, D.W. 2001. Molecular Cloning: A Laboratory Manual. Cold Spring Harbor Laboratory Press. http://dx.doi.org/10.1002/jobm.3620300824

SOLAIMAN, D.Y., ASHBY, R., HOTCHKISS, A.J.R., FOGLIA, T. 2006 Biosynthesis of Medium-chain-length Poly(hydroxyalkanoates) from Soy Molasses. Biotechnology letters, 28, 157-162. http://dx.doi.org/10.1007/s10529. 005-5329-2

TAJIMA, K., HAN, X., SATOH, Y., ISHII, A., ARAKI, Y., MUNEKATA, M., TAGUCHI, S. 2012. In vitro synthesis of polyhydroxyalkanoate (PHA) incorporating lactate (LA) with a block sequence by using a newly engineered thermostable PHA synthase from Pseudomonas sp. SG4502 with acquired LApolymerizing activity. Applied microbiology and biotechnology, 94(2), 365-376 http://dx.doi.org/10.1007/s00253-011-3840-z

TAN, Y., NEO, P. C., NAJIMUDIN, N., SUDESH, K., MUHAMMAD, T. S. T. OTHMAN, A. S., SAMIAN, R. 2010. Cloning and characterization of poly (3hydroxybutyrate) biosynthesis genes from Pseudomonas sp. USM 4-55. Journal

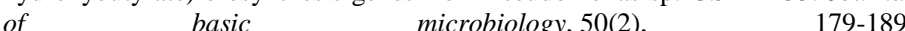
http://dx.doi.org/10.1002/jobm.200900138

WANG, Y., YIN, J., CHEN, G.Q. 2014. Polyhydroxyalkanoates, challenges and opportunities. Current opinion in biotechnology, 30, 59-65. http://dx.doi.org/10.1016/j.copbio.2014.06.001

YANG, C., WEI, Z., RUIHUA, L., CHI, Z., TING, G., QIANG, L.I., SHUFANG, W., CUNJIANG, S. 2013. Analysis of polyhydroxyalkanoate (PHA) synthase gene and PHA-producing bacteria in activated sludge that produces PHA containing 3-hydroxydodecanoate. FEMS microbiology letters, 346(1), 5664. http://dx.doi.org/10.1111/1574-6968.12201

ZHU, C., NOMURA, C.T., PERROTTA, J.A., STIPANOVIC, A.J., NAKAS, J.P. 2010. Production and characterization of poly-3-hydroxybutyrate from biodiesel-glycerol by Burkholderia cepacia ATCC 17759. Biotechnology Progress, 26, 424-430. http://dx.doi.org/10.1002/btpr.355 